\title{
Layanan Bimbingan Konseling melalui Pendekatan Agama untuk Mengatasi Kenakalan Remaja
}

\author{
Indri Novionita Lena* \\ Jurusan Bimbingan dan Konseling Islam UIN Sunan Gunung Djati, Bandung \\ *Email : indrinovionita@gmail.com
}

\begin{abstract}
The article aims to reveal the guidance counseling program, the implemetation of the guidance counseling through the religion approach and the result of implementatiob of the guidance counseling through the religion approach to evercome delinquency teenagers. The research using the deskriptif through the kualitatif of explain the fact that there are with the way explained or describe the results of research about the services guidance counseling through the religion approach to evercome delinquency teenagers. The results of research suggest that the services guidance counseling through the religion approach through the reading and examines al-Qur'an and Asmaul Husna, spirituality, Friday Prayer, Dhuba Prayer can change the students toward more positive as students who often skipping be reduced, there is no longer students who smoking, students are reminded with this friend, think back when wills do the behavior deviate because ealized delinquency teenagers probibited bay religion, bebave and dressed more politely and alto more disipliner.
\end{abstract}

Keywords: Guidance Counseling; Religion Aprroach; Delinquency teenagers

\section{ABSTRAK}

Tulisan ini bertujuan untuk mengungkapkan program bimbingan konseling, pelaksanaan kegiatan bimbingan konseling melalui pendekatan agama dan hasil kegiatan bimbingan konseling melalui pendekatan agama untuk mengatasi kenakalan remaja. Metode penelitian menggunakan metode deskriptif melalui pendekatan kualitatif untuk menjelaskan fakta yang ada dengan cara memaparkan atau menggambarkan hasil penelitian tentang layanan bimbingan konseling melalui pendekatan agama untuk mengatasi kenakalan remaja. Hasil

Diterima: Januari 2019. Disetujui: Februari 2019. Dipublikasikan: Maret 2019. 
penelitian menunjukkan bahwa layanan bimbingan konseling melalui pendekatan agama melalui kegiatan membaca dan mengkaji al-Qur'an dan Asmaul Husna, kerohanian, shalat jum'at dan shalat dhuha dapat merubah siswa ke arah yang lebih positif seperti siswa yang sering bolos menjadi berkurang, tidak ada lagi siswa yang merokok, siswa saling mengingatkan dengan temannya, berpikir kembali ketika akan melakukan perilaku menyimpang karena menyadari kenakalan remaja dilarang oleh agama, berperilaku dan berpakian lebih sopan, dan juga lebih disiplin.

Kata Kunci : Bimbingan Konseling; Pendekatan Agama; Kenakalan Remaja

\section{PENDAHULUAN}

Pada masa remaja terjadi berbagai macam perubahan yang cukup bermakna, baik secara fisik, biologis, mental dan emosional serta psikososial. Semua ini dapat mempengaruhi kehidupan pribadi, lingkungan keluarga maupun masyarakat. Ketidakpuasan remaja dalam menghadapi perubahan tersebut dapat menimbulkan berbagai perilaku menyimpang seperti kenakalan remaja. Begitupun saat berada di sekolah, remaja sering kali melakukan penyimpangan seperti tidak mentaati peraturan sekolah, malas belajar, merokok, tawuran, dan sebagainya sehingga terjadi kenakalan remaja di sekolah. Seorang siswa dalam mengikuti kegiatan belajar di sekolah tidak akan lepas dari berbagai peraturan dan tata tertib yang diberlakukan di sekolahnya dan setiap siswa dituntut untuk dapat berperilaku sesuai dengan aturan dan tata tertib yang diberlakukan di sekolahnya. Namun sekolah tidak bisa dilepaskan dari persoalan perilaku negatif siswa. Perilaku negatif yang terjadi di kalangan remaja pada akhir-akhir ini sudah tampak mengkhawatirkan, seperti kehidupan seks bebas, keterlibatan dalam narkoba, geng motor dan berbagai tindakan yang menjuru ke arah kriminal lainnya, yang tidak hanya dapat merugikan diri sendiri tetapi juga masyarakat umum. Dampak kenakalan remaja yang paling nampak memang dalam hal pergaulan. Sampai saat ini, masih banyak para remaja yang terjebak dalam pergaulan yang tidak baik. Mulai dari pemakaian obat-obatan terlarang sampai seks bebas.

Kenakalan remaja pasti berdampak pula pada keluarga terutama orang tua. Banyak orang tua yang mengeluh karena anaknya malas belajar, lalu dengan serta merta mengarahkan telunjuknya kepada anak-anak mereka untuk mencari objek penderita. Kemalasan remaja kebanyakan disebabkan oleh kurangnya ilmu sehingga mereka tidak tahu tentang manfaat belajar, sakit hingga menurunkan motivasi dirinya, kelelahan karena banyak kegiatan selain belajar, patah hati atau kehilangan sesuatu yang disayanginya sehingga cenderung menghabiskan waktunya untuk merenung dari pada belajar. Orang tua harus mengontrol dan 
mengawasi anaknya dengan melarang hal-hal tertentu. Namun bagi sebagian remaja larangan-larangan tersebut malah dianggap hal yang buruk dan mengekang. Akibatnya mereka memberontak dengan berbagai cara.

Pergaulan remaja Indonesia belakangan ini semakin tak karuan. Sepertinya sudah tak terhitung berapa foto-foto yang beredar di dunia maya yang menunjukkan pergaulan remaja yang sudah kebablasan. Mulai dari pose merokok, mabuk-mabukan hingga pergaulan bebas yang menjurus ke seks bebas bahkan kasus pemerkosaan dan pembunuhan yang pelakunya masih berusia remaja. Berdasarkan pantauan tim Harian Indo di media sosial Facebook, Kamis (19/5/2016), belum lama ini kembali heboh di Facebook setelah tersebarnya sebuah foto yang menunjukkan beberapa gadis SMA yang sedang asyik menghisap rokok. Bahkan salah satu diantara mereka asyik merokok sambil berangkulan dengan pacarnya (Soraya: 2016).

Krisis identitas pada diri siswa diusia remaja sering kali menimbulkan kendala dalam penyesuaian diri terhadap kegiatan belajarnya. Pada umumnya, remaja sebenarnya mengetahui bahwa untuk menjadi orang yang sukses harus rajin belajar. Namun, karena dipengaruhi oleh upaya pencarian identitas diri yang kuat menyebabkan mereka sering kali lebih senang mencari kegiatan selain belajar tetapi menyenangkan bersama teman-temannya. Akhirnya, seringkali ditemui remaja yang malas dan tidak disiplin dalam belajar. Selain itu, kurangnya pengetahuan keagamaan juga dapat menimbulkan kenakalan pada remaja.

Bimbingan konseling melalui pendekatan agama terhadap siswa bertujuan untuk membuat siswa memiliki kepribadian yang islami. Dengan karakter moral yang baik, prinsip-prinsip islami yang kuat, memiliki sarana untuk menghadapi tuntutan hidup dengan cara yang matang dan bertanggungjawab. Pendekatan agama menjadi unsur terpenting dalam pembangunan mental sebagai pengobat terhadap kejiwaan yang masih labil seperti siswa diusia remaja disamping kesadaran agamanya relatif rendah, karenanya pendidikan keagamaan yang diterima di rumah tidak boleh berbeda dari apa yang diterimanya di sekolah. Untuk itu diperlukan peran guru pembimbing dalam membimbing akhlak para siswa agar mereka tidak melakuakn perbuatan-perbuatan yang dilarang oleh agama. Seperti yang terjadi di lokasi penelitian yaitu SMP NEGERI I IBUN, bahwa upaya yang dilakukan dalam mengatasi kenakalan siswa adalah dengan bimbingan konseling melalui pendekatan agama. Sekolah tersebut tidak hanya mengatasi kenakalan siswa melalui kegiatan bimbingan dan konseling yang biasa dilakukan di ruang BK tetapi guru BK sering mengadakan bimbingan konseling melalui pendekatan agama setiap satu Minggu sekali dengan mendatangkan orang yang dapat memberikan bimbingan tersebut kepada siswa.

Penelitian terdahulu menjadi salah satu acuan dalam melakukan penelitian ini. Berdasarkan penelitian dalam skripsi yang berjudul Analisis Empiris tentang 
Bimbingan Agama untuk Membangun Akhlakul Karimah Remaja menunjukkan bahwa remaja yang tadinya berperilaku kurang baik seperti tutur katanya kasar, berpakaian tidak sopan, berperilaku kurang hormat, dan lalai dalam beribadah, setelah diadakan bimbingan agama terjadi beberapa perubahan seperti tutur katanya menjadi lebih sopan, berpakain rapi, berperilaku sopan dan hormat karena diarahkan oleh pembimbing dan melihat teman yang lainnya, ibadah remaja yang tadinya sering lalai sedikit demi sedikit berubah ke arah yang lebih baik (Sahaburohman, 2016: 91).

Penelitian terdahulu yang berkaitan dengan kenakalan remaja atara lain:

Penelitian Khermarinah, K. (2017) berjudul Problematika Kenakalan Pada Kalangan Remaja. Penelitian Tamayao I.,(2017). Berjudul Efektifitas Metode Pendekatan Sosiologi Personal Dalam Meminimalisasi Terhadap Kenakalan Remaja, Penelitian Dewi, Y., (2017). Berjudul Faktor Penyebab Tergabungnya Remaja Kota Bandung Dalam Komunitas Kenakalan Remaja. Penelitian penelitian tersebut memiliki kajian yang berbeda yaitu mengkaji problematika kenakalan remaja, meminimalisasi kenakalan remaja dengan pendekatan sosiologi, dan mengkaji latar belakang tergabungnya komunitas kenakalan remaja - Sedangkan penelitian penulis mengkaji upaya penanggulangan kenakalan remaja dengan layanan bimbingan dan konseling.

Adapun penelitian terdahulu berkenaan dengan bimbingan konseling antara lain: Penelitian Merryana, (2013). Peran Bimbingan Konseling (Bk) Dalam Mengatasi Kenakalan Remaja Di Sekolah Menengah Pertama Negeri, penelitian

Yandri, dkk. (2013) berjudul Pengembangan Modul Bimbingan Dan Konseling Untuk Pencegahan Bullying Di Sekolah dan penelitian Dwinita, D., (2012). Berjudul Pelaksanaan Bimbingan Konseling Anak Berkebutuhan Khusus Di SMKN 4 Padang. Membahas memiliki objek kajian yang berbeda dengan kajian peneliti yaitu pada objek dan sasarannya.

Dari penjabaran di atas, maka penetlitian ini dilakukan untuk meneliti bagaimana pelaksanaan bimbingan konseling melalui pendekatan agama yang ada di sekolah ini karena peneliti melihat bimbingan ini jarang sekali dilakukan di SMP pada umumnya dan bimbingan konseling melalui pendekatan agama ini sangat penting untuk menciptakan kepribadian yang islami pada siswa.

Penelitian tentang layanan bimbingan dan konseling melaui pendekatan agama dalam mengatasi kenakalan remaja dilakukan di SMP NEGERI I IBUN Jalan Panggilingan NO. 1 Desa Talun Kecamatan Ibun Kabupaten Bandung dengan alasan Siswa SMP merupakan anak dalam usia remaja yang sering kali melakukan kenakalan dan SMP NEGERI I IBUN memiliki program layanan bimbingan dan konseling melalui pendekatan agama.

Untuk mempermudah dalam menganalisis hasil penelitian, maka penelitian ini difokuskan pada program bimbingan konseling melalui pendekatan agama di 
SMPN I Ibun yang meliputi kegiatan bimbingan membaca dan mengkaji AlQur'an, membaca dan mengkaji Asmaul Husna, bimbingan kerohanian, Shalat Jum'at, dan Shalat Dhuha berjamaah.

Metode penelitian yang digunakan adalah metode deskriptif melalui pendekatan kualitatif. Alasan penggunaan metode ini adalah ingin menjelaskan fakta yang ada dengan cara memaparkan atau menggambarkan hasil penelitian tentang layanan bimbingan konseling melalui pendekatan agama untuk mengatasi kenakalan remaja.

\section{LANDASAN TEORITIS}

Teori yang dijadikan landasan dalam penelitian ini adalah teori bimbingan konseling Islam dan kenakalan remaja. "Bimbingan adalah bantuan yang diberikan oleh yang ahli kepada seorang atau beberapa individu, baik anak-anak, remaja maupun dewasa" (Satriah, 2015: 1). Bimbingan tersebut diberikan agar individu mampu menentukan pilihan-pilihannya. Seperti yang dikemukakan oleh Sofyan Willis (2014: 11) mengemukakan bahwa, "Dalam bimbingan ada dua orang yakni pembimbing dan yang dibimbing, dimana pembimbing membantu si terbimbing sehingga si terbimbing mampu membuat pilihan-pilihan." Sejalan dengan pengertian tersebut, bimbingan dan konseling di sekolah diberikan kepada siswa sebagai upaya menemukan pribadi, mengenal lingkungan, dan merencanakan masa depannya. Pengertian konseling menurut Aminarti (2013: 15) yaitu, "Konseling merupakan serangkaian kegiatan paling pokok dari bimbingan dalam usaha membantu konsili/klien secara tatap muka dengan tujuan agar klien dapat mengambil tanggung jawab sendiri terhadap berbagai persoalan atau masalah khusus." Dalam proses konseling terlihat adanya suatu masalah yang terjadi pada konseli yang perlu mendapatkan pemecahan. Cara pemecahannya yaitu sesuai dengan keadaan konseli itu sendiri. Jadi proses konseling itu memiliki tujuan tertentu, yaitu pemecahan masalah yang dihadapi konseli itu sendiri. Dari pengertian tersebut dapat dinyatakan bahwa dapat dinyatakan bahwa bimbingan dan konseling adalah suatu proses pemberian bantuan kepada individu yang sedang mengalami masalah, dilakukan secara berkelanjutan dan sistematis oleh seorang ahli yang telah mendapat latihan khusus untuk itu, dengan tujuan agar individu dapat memahami dirinya, lingkungannya, mengatasi masalahnya, dan merencanakan masa depannya dengan baik.

Secara umum bimbingan dan konseling dalam keseluruhan bimbingan di lembaga pendidikan adalah membantu seluruh peserta didik melalui pelayanan (yang tertuju kepada masing-masing) pribadi agar mencapai tahap perkembangan optimal baik secara akademis, psikologis maupun sosial. Menurut Arya (2008: 15) terdapat beberapa jenis bimbingan konseling, yaitu bimbingan akademik, Irsyad : Jurnal Bimbingan, Penyuluhan, Konseling, dan Psikoterapi Islam 7(1) (2019) 19-40 
bimbingan pribadi sosial, bimbingan karir, bimbingan konseling melalui pendekatan agama. Bimbingan diperuntukkan bagi semua individu (guidance si for alk individual), bimbingan bersifat individualisasi, bimbingan menekankan hal yang positif, bimbingan merupakan usaha bersama, pengambilan keputusan merupakan hal yang esensial dalam bimbingan, bimbingan berlangsung dalam berbagai setting kehidupan.

Bimbingan dan konseling melalui pendekatan agama adalah usaha pemberian bantuan kepada seseorang yang mengalami kesulitan baik lahiriah maupun batiniah yang mneyangkut kehidupannya di masa kini dan masa mendatang. Bantuan tersebut berupa pertolongan di bidang mental dan spiritual, agar orang yang bersangkutan mampu mengatasinya dengan kemampuan yang ada pada dirinya sendiri maupun dorongan dari kekuatan iman dan takwa kepada Tuhan. Bimbingan konseling keagamaan dapat dilakukan melalui beberapa jenis layanan, diantaranya dapat dilakukan melalui shalat, dzikir, shaum, nasihat.

Shalat merupakan bentuk kegiatan yang menggabungkan antara kegiatan fisik dan non fisik. Beberapa pakar ilmu jiwa mencoba melakukan tajribat (uji coba) terhadap pengaruh shalat bagi kesehatan jiwa. Dzikir diyakini dapat membuat hati menjadi tenang. Ketenangan hati membuahkan bersihnya pikiran dan sehatnya jasmani. Selain dzikir sebagai ibadah yang diwajibkan Allah, sebagaimana shalat dan ibadah lainnya. Dzikir juga dinilai mempunyai efek terapi terhadap mereka yang sedang mengalami gangguan jiwa. Dzikir memiliki nilai magis, di samping berfungsis sebagai bagian dari seni, dzikir juga memiliki daya sentuh pada proses penyehatan jiwa. Shaum merupakan ibadah yang membutuhkan kesabaran. Seseorang akan dididik disiplin meskipun tidak ada orang lain yang melihatnya. Shaum adalah sebuah pengabdian dengan cara menahan makan dan minum, termasuk menahan diri dari segala yang membuat kerusakan shaum. Shaum juga termasuk jenis terapi jiwa yang pelakunya hampir tidak menyadaei. Kaum muslimin dituntut untuk menahan hal-hal yang dianggap dapat membatalkannya. Dalam hal ini jiwa dilatih untuk menuju manusia yang berakhlaq al-karimah. Mengatasi atau menasehati, bahkan membimbing ke arah jalan Allah merupakan cara utama dalam bimbingan konseling keagamaan. Nasihat sendiri merupakan cara efektif untuk memberikan peringatan ataupun pengajaran kepada manusia agar terbebas dari segala bentuk kebodohan. Nasihat yang baik mengandung bimbingan disamping setumpuk penjelasan atau ceramah-ceramah. Nasihat yang mudah untuk dicerna adalah yang sesuai dengan kebutuhan jiwanya. Juga dielaraskan dengan kemampuan berpikir dan kemampuan akalnya. Bimbingan menggunakan nasihat merupakan upaya konselor untuk menjelaskan sisi penyebab dan akibat kepada konseli (siswa). Dan juga memberikan arahan mengenai keadaan yang benar berdasarkan ilmu pengetahuan. Konselor Islam dibekali tentang ilmu dakwah dalam menyampaikan nasihat (Fajar, 2015: 67). "Sumber ilmu dakwah adalah al24 
Qur'an, al-Sunnah, serta produk ijtihad. Al-Qur'an diyakini sebagai sumber segala ilmu dakwah karena di dalamnya terdapat isyarat yang jelas mengenai apa, bagaimana, dan untuk apa kegunaan dakwah islamiyah" (Sukayat, 2012: 201).

Bimbingan dan konseling melalui pendekatan agama, dapat dilakukan dengan meyakinkan individu tentang posisi manusia sebagai makhluk Allah, mendorong dan membantu individu memahami dan mengamalkan ajaran agama secara benar, mendorong dan membantu individu memahami dan mengamalkan iman, islam, dan ikhsan (Sutoyo 2013: 214).

Remaja adalah masa peralihan dari anak menuju dewasa, pada masa ini terjadi berbagai perubahan baik secara fisik, psikologis, mental, dan emosional serta psikososial. Karakteristik Umum Perkembangan Remaja diantaranya, kegelisahan, pertentangan, mengkhayal, aktivitas berkelompok, keinginan mencoba segala sesuatu.

Remaja yang berada dalam masa transisi membuat remaja dihadapkan pada berbagai kontradiksi. Masa remaja merupakan masa peralihan dari masa kanak-kanak kemasa dewasa yang lebih matang dan mampu berdiri sendiri, sehingga remaja selalu memikirkan nilai dan standar moral yang muncul dari agama dan lingkungan sosial (Marlina, 2012: 250).

Kenakalan remaja adalah perilaku jahat yang terjadi pada anak-anak remaja secara sosial yang disebabkan oleh satu bentuk pengabaian sosial, sehingga mereka mengembangkan bentuk tingkah laku yang menyimpang dan tidak sesuai dengan ajaran norma yang berlaku. Terdapat beberapa jenis kenakalan yang dilakukan oleh para remaja, diantaranya penggunaan narkoba, perkelahian atau tawuran, minum minuman keras, penipuan, perjudian, pemerasan, seks bebas, pencurian, penganiayaan, balapan liar, bolos sekolah, pembunuhan dengan latar belakang geng/kelompok. Ada beberapa faktor-faktor yang mempengaruhi kenakalan remaja, yaitu identitas, kontrol diri, usia, jenis kelamin, harapan terhadap pendidikan dan nilai-nilai di sekolah, proses keluarga, pengaruh teman sebaya, kelas sosial ekonomi, kualitas lingkungan sekitar tempat tinggal (Willis, 1994: 10).

Upaya mengatasi kenakalan remaja menurut pendidikan Islam yaitu ikhtiar pencegahan yang bersifat umum meliputi usaha pembinaan pribadi remaja sejak masih dalam kandungan melalui ibunya, setelah lahir, anak-anak perlu diasuh dan dididik dalam suasana yang stabil, pendidikan dalam lingkungan sekolah, pendidikan luar sekolah dan rumah tangga, Perbaikan lingkungan dan kondisi sosial. Usaha-usaha pencegahan yang bersifat khusus meliputi pengawasan, bimbingan dan penyuluhan, pendekatan-pendekatan khusus terhadap remaja yang sudahmenunjukkan gejala-gejala kenakalan perlu dilakukan sedini mungkin.

\section{HASIL DAN PEMBAHASAN}


Penelitian ini dilakukan di SMP Negeri I Ibun, tepatnya beralamat di Jalan Panggilingan No. 1 Desa Talun Kecamatan Ibun. Dengan kepala sekolah Bapak Dindin Sutardin S.Pd.,M.M. Kondisi pada tahun pelajaran 2017-2018 jumlah siswa 1.327 orang dengan jumlah rombongan belajar sebanyak 36 rombel. Jumlah guru PNS sebanyak 53 orang sedangkan guru honor sebanyak 17 orang. Jumlah tenaga administrasi sekolah saat ini ada 3 orang PNS sedangkan honorer sebnayak 18 orang. Visi SMPN I Ibun yaitu mewujudkan suasana sekolah dan suasana pembelajaran yang kondusif demi terciptanya insan yang berkepribadian mandiri, sehat, cerdas, agamis dan mampu mengembangkan potensi diri (Wawancara dengan kepala sekolah, SMPN I Ibun: 01 Februari 2018).

Semua pendidik memiliki silabus sesuai mata pelajaran yang diampunya. Silabus dikembangkan didasarkan pada standar isi, standar kompetensi lulusan dan KTSP. Silabus mengarah pada pencapaian SKL hanya belum dikaji setiap tahun untuk disesuaikan dengan perubahan kebutuhan pembelajaran. Sumber belajar yang tersedia buku teks, buku referensi, perpustakaan, laboratorium, lingkungan, internet. Buku teks belum sesuai, tidak mencukupi untuk satu siswa satu buku. Pemanfaatan lingkungan dan perpustakaan sebagai sumber belajar masih rendah. Metode pembelajaran interaktif belum dipergunakan oleh sebagian besar guru. Ada penghargaan untuk peserta didik yang berprestasi. Pendidik selalu memberi pengaruh terhadap hasil belajar peserta didik dalam proses pembelajaran berlangsung (Dokumen SMPN I Ibun, 2017: 5-18).

Sarana ruang kelas sudah memadai, hanya 10\% yang kondisinya masih perlu perbaikan. Ruang kepala sekolah, ruang guru, ruang tata usaha, masjid, ruang kesiswaan dan ekstrakurikuler, ruang sirkulasi, lapang olahraga, laboratorium IPA, jamban, tempat bermain sudah memadai. Yang masih perlu dilengkapi dan diperbaiki adalah ruang perpustakaan, lab komputer, multimedia, UKS, konseling, dan gudang. RAPBS sudah dirumuskan merujuk pada peraturan pemerintah, melibatkan kepala sekolah. Sekolah sudah melakukan pembukaan keuangan yang dilengkapi dengan bukti pengeluaran yang sah tetapi tidak memajang laporan kinerja efektivitas anggaran di pengumuman sekolah. Pendapatan dan pengeluaran keuangan sekolah dilaporkan secara periodik kepada pemerintah dan pemangku kepentingan dan sudah melakukan pertanggung jawaban penggunaan keuangan secara menyeluruh kepada pemerintah dan pemangku kepentingan. Sekolah membebaskan semua peserta didik dari segala bentuk pembiayaan penyelenggaraan pengeluaran keuangan sekolah (Dokumen SMPN I Ibun, 2017: 5-18).

\section{Program Bimbingan Konseling di SMPN I Ibun}

Bimbingan dan konseling di SMPN I Ibun lebih berorientasi pada pengenalan potensi, kebutuhan, dan tugas perkembangan serta pemenuhan kebutuhan dan 
tugas-tugas perkembangan sebagaimana tercantum dalam Standar Kompetensi Kemandirian Peserta Didik (SKKPD). Pemenuhan perkembangan optimal dan pencegahan terjadinya masalah merupakan fokus pelayanan. Bimbingan dan konseling saat ini tertuju pada mengenali kebutuhan peserta didik, orang tua, dan sekolah. Dalam pelaksanaan program bimbinngan dan konseling dilaksanakan secara utuh dan kolaboratif dengan seluruh stakeholder sekolah. Visi BK SMPN I Ibun yaitu mengembangkan seluruh aspek kepribadian seluruh siswa SMP Negeri I Ibun, sehingga terwujud siswa yang mandiri, sehat, cerdas, agamis, dan mampu mengembangkan potensi dalam dirinya (Dokumen BK SMPN I Ibun, 2017: 2).

Tabel. 1 Rumusan Kebutuhan dan Tujuan Bimbingan dan Konseling

\begin{tabular}{|c|c|}
\hline Rumusan Kebutuhan & $\begin{array}{c}\text { Tujuan Bimbingan dan } \\
\text { Konseling }\end{array}$ \\
\hline $\begin{array}{l}\text { Melaksanakan ibadah dengan kemauan } \\
\text { sendiri }\end{array}$ & $\begin{array}{l}\text { Peserta didik melaksanakan ibadah } \\
\text { dengan kemauan sendiri }\end{array}$ \\
\hline $\begin{array}{l}\text { Memahami dan mengamalkan ajaran } \\
\text { agama Islam }\end{array}$ & $\begin{array}{l}\text { Peserta didik mampu memahami } \\
\text { dan mengamalkan ajaran agama } \\
\text { Islam }\end{array}$ \\
\hline Kemampuan tertib \& patuh & $\begin{array}{l}\text { Peserta didik mampu tertib dan } \\
\text { patuh terhadap aturan }\end{array}$ \\
\hline Kemampuan mengendalikan emosi & $\begin{array}{l}\text { Peserta didik mampu } \\
\text { mengendalikan emosi dengan baik }\end{array}$ \\
\hline \multirow{2}{*}{$\begin{array}{l}\text { Menentukan alternatif pemecahan } \\
\text { masalah }\end{array}$} & $\begin{array}{l}\text { Peserta didik dapat menentukan } \\
\text { berbagai alternatif dalam } \\
\text { pemecahan masalah }\end{array}$ \\
\hline & $\begin{array}{l}\text { Peserta didik mampu menghormat } \\
\text { dan peduli terhadap lingkungan } \\
\text { sekitar }\end{array}$ \\
\hline $\begin{array}{l}\text { Hormat dan peduli terhadap lingkungan } \\
\text { sekitar }\end{array}$ & $\begin{array}{l}\text { Peserta didik berperilaku sesuai } \\
\text { dengan jenis kelamin masing- } \\
\text { masing }\end{array}$ \\
\hline Berperilaku sesuai gender & $\begin{array}{l}\text { Peserta didik memiliki kepercayaan } \\
\text { diri yang tinggi }\end{array}$ \\
\hline \multirow[t]{2}{*}{ Kepercayaan diri tinggi } & $\begin{array}{l}\text { Peserta didik memiliki kemampuan } \\
\text { berhemat dan menabung }\end{array}$ \\
\hline & $\begin{array}{l}\text { Peserta didik memiliki cita-cita } \\
\text { yang sesuai minat, bakat dan }\end{array}$ \\
\hline
\end{tabular}

Irsyad : Jurnal Bimbingan, Penyuluhan, Konseling, dan Psikoterapi Islam 7(1) (2019) 19-40 
I.N. Lena

Berperilaku hemat dan menabung

Memiliki cita-cita

Kesungguhan belajar

Memahami bakat, kemampuan dan minat

melanjutkan studi kemampuan

Peserta didik memiliki

kesungguhan belajar

Peserta didik dapat melanjutkan sekolah sesuai minat, bakat dan kemampuannya

Peserta didik dapat bekerja sama dengan orang lain yang berbeda latar belakang

Mampu bekerja sama dengan orang lain

Sumber: Wawancara dengan Guru BK, SMPN I Ibun: 03 Februari 2018

Berdasarkan Tabel. 1, hasil kajian informasi mengenai gambaran kondisi umum siswa, maka diperoleh kebutuhan siswa akan layanan bimbingan dan konseling yaitu, Sebagian besar siswa kelas VII, VIII, dan IX SMP Negeri I Ibun membutuhkan bimbingan yang sifatnya pengembangan melalui layanan bimbingan dasar yang bersifat informatif untuk meningkatkan 8 aspek perkembangan terendah khususnya pada landasan hidup religius, kematangan dan kesadaran bertanggung jawab kepada luruh siswa (Wawancara dengan Guru BK, SMPN I Ibun: 03 Februari 2018).

Komponen program bimbingan dan konseling di SMPN I Ibun meliput layanan dasar, layanan peminatan dan perencanaan individual, layanan responsif, dukungan sistem. Layanan dasar adalah proses pemberian bantuan kepada semua peserta didik/konseli yang berkaitan dengan pengembangan keterampilan, dan sikap dalam bidang pribadi, sosial, belajar, dan karier yang diperlukan dalam pelaksanaan tugas-tugas perkembangan mereka. Layanan peminatan dan perncanaan individual merupakan proses pemberian bantuan kepada semua peserta didik/konseli dalam membuat dan mengimplementasikan rencana pribadi, sosial, belajar, dan karier. Layanan responsif adalah pemberian bantuan terhadap peserta didik/konseli yang memiliki kebutuhan dan masalah yang memerlukan bantuan dengan segera. Dukungan sistem merupakan semua aktivitas yang dimaksudkan untuk mendukung dan meningkatkan staf bimbingan dan konseling dalam melaksanakan layanan Dasar, layanan peminatan dan perencanaan individual, layanan responsif, Staf personalia sekolah yang lain dalam melaksanakan program-program pendidikan di sekolah. Setelah guru bimbingan dan konseling atau konselor menentukan layanan, berikutnya yang juga penting dipertimbangkan adalah porsi waktu dari masing-masing komponen 
layanan. Perencanaan waktu ini didasarkan kepada program dan dukungan manajemen yang harus dilakukan oleh konselor (Dokumen BK SMPN I Ibun, 2017: 9).

Bimbingan dan konseling pada satuan pendidikan mencakup empat bidang layanan, yaitu bidang layanan yang memfasilitasi perkembangan pribadi, sosial, belajar, karier dan keagamaan. Pada hakikatnya perkembangan tersebut merupakan satu kesatuan utuh yang tidak dapat dipisahkan dalam setiap diri individu siswa/konseli. Bidang pribadi yaitu suatu proses pemberian bantuan dari guru bimbingan dan konseling atau konselor kepada siswa/konseli untuk memahami, menerima, mengarahkan, mengambil keputusan, dan merealisasikan keputusannya secara bertanggung jawab tentang perkembangan aspek pribadinya, sehingga dapat mencapai perkembangan pribadinya secara optimal dan mencapai kebahagiaan, kesejahteraan dan keselamatan dalam hidupnya. Bidang sosial yaitu suatu proses pemberian bantuan dari konselor kepada siswa/konseli untuk memahami lingkungannya dan dapat melakukan interaksi sosial secara positif, terampil berinteraki sosial, mampu mengatasi masalahmasalah sosial yang dialaminya, mampu menyesuaikan diri dan memiliki keserasian hubungan dengan lingkungan sosialnya sehingga mencapai kebahagiaan dan kebermaknaan dalam hidupnya. Bidang karir yaitu proses pemberian bantuan guru bimbingan dan konseling atau konselor kepada siswa/konseli untuk mengalami pertumbuhan, perkembangan, eksplorasi, aspirasi dan pengambilan keputusan karier sepanjang rentang hidupnya secara rasional dan realistis berdasar informasi potensi diri dan kesempatan yang tersedia di lingkungan hidupnya sehingga mencapai kesuksesan dalam hidupnya. Bidang keagamaan yaitu proses pemberian bantuan guru bimbingan dan konseling kepada siswa untuk menambah pengetahuan keagamaan siswa, menanamkan nilai-nilai keagamaan pada siswa, agar siswa selalu melakukan perbuatan yang baik, beribadah dengan ikhlas, dan mengamalkan ajaran agama (Wawancara dengan Guru BK, SMPN I Ibun: 10 Februari 2018).

Tabel. 2 Tema dalam Penyusunan Rencana Pelaksanaan Layanan BK

\begin{tabular}{cccl}
\hline $\begin{array}{c}\text { Rumusan } \\
\text { Kebutuhan }\end{array}$ & $\begin{array}{c}\text { Bidang } \\
\text { Layanan }\end{array}$ & Kelas & \multicolumn{1}{c}{ Tema yang Dikembangkan } \\
\hline Ibadah & $\begin{array}{l}\text { Bimbingan } \\
\text { pribadi }\end{array}$ & VII & Arti dan tujuan ibadah \\
& VIII & Bentuk Ibadah \\
& IX & Bagaimana aku beribadah?
\end{tabular}


I.N. Lena

\begin{tabular}{|c|c|c|c|}
\hline \multirow[t]{5}{*}{ Agama } & \multirow[t]{5}{*}{$\begin{array}{l}\text { Bimbingan } \\
\text { pribadi-sosial }\end{array}$} & VII & $\begin{array}{l}\text { Cara membaca dan memahami ayat al-Qur'an } \\
\text { dan Asmaul Husna }\end{array}$ \\
\hline & & \multirow{4}{*}{ IX } & Aqidah Islam \\
\hline & & & Mengapa harus patuh? \\
\hline & & & Aturan/norma \\
\hline & & & Bagaimana aku patuh? \\
\hline \multirow{5}{*}{ Tertib\&patuh } & \multirow{5}{*}{$\begin{array}{l}\text { Bimbingan } \\
\text { pribadi-sosial }\end{array}$} & \multirow{5}{*}{$\begin{array}{c}\text { VII } \\
\text { VIII } \\
\text { IX }\end{array}$} & Ragam ekspresi emosi \\
\hline & & & Mengendalikan emosi \\
\hline & & & Mengelola stress \\
\hline & & & Gaya belajar asertif \\
\hline & & & Mengambil keputusan \\
\hline \multirow{4}{*}{$\begin{array}{l}\text { Pengendalian } \\
\text { emosi }\end{array}$} & \multirow{4}{*}{$\begin{array}{l}\text { Bimbingan } \\
\text { pribadi }\end{array}$} & \multirow{2}{*}{$\begin{array}{l}\text { VII } \\
\text { VIII }\end{array}$} & Hak dan kewajiban \\
\hline & & & Keharmonisan hidup \\
\hline & & \multirow{2}{*}{ IX } & Peduli terhadap sesama \\
\hline & & & Konsep diri positif \\
\hline \multirow{4}{*}{$\begin{array}{l}\text { Berpikir } \\
\text { secara } \\
\text { alternatif }\end{array}$} & \multirow{4}{*}{$\begin{array}{l}\text { Bimbingan } \\
\text { pribadi, belajar }\end{array}$} & & Percaya diri \\
\hline & & VII & Cita-citaku \\
\hline & & VIII & Tidak menyontek \\
\hline & & IX & Karier setelah SMP \\
\hline \multirow[t]{2}{*}{$\begin{array}{l}\text { Peduli } \\
\text { terhadap } \\
\text { sekitar }\end{array}$} & \multirow[t]{2}{*}{ Bimbingan sosial } & VII & \\
\hline & & VIII & \\
\hline \multirow[t]{7}{*}{$\begin{array}{l}\text { Kepercayaan } \\
\text { diri }\end{array}$} & \multirow[t]{2}{*}{$\begin{array}{l}\text { Bimbingan } \\
\text { pribadi }\end{array}$} & IX & \\
\hline & & VII & \\
\hline & \multirow{5}{*}{$\begin{array}{l}\text { Bimbingan } \\
\text { belajar, karier }\end{array}$} & VIII & \\
\hline & & IX & \\
\hline & & VII & \\
\hline & & VIII & \\
\hline & & IX & \\
\hline
\end{tabular}

Sumber: Dokumen BK SMPN I Ibun, 2017: 16 
Berdasarkan Tabel. 2, rencana kegiatan (Action Plan) bimbingan dan konseling merupakan rencana detail yang menguraikan tindakan-tindakan yang diperlukan untuk mencapai tujuan yang didapat dari hasil asesmen terhadap kondisi siswa serta standar kompetensi kemandirian siswa. Tema topik merupakan rincian lanjut dari identifikasi kebutuhan peserta didik/konseli dalam aspek perkembangan pribadi, sosial, belajar dan karier yang dituangkan dalam rencana pelaksanaan layanan bimbingan dan konseling. Bidang-bidang layanan yang yang diperlukan siswa dapat dikembangkan menjadi beberapa tema (RPL, BK) (Dokumen BK SMPN I Ibun, 2017: 16).

Dalam evaluasi program bimbingan dan konseling terdapat dua jenis evaluasi, yaitu evaluasi prose dan evaluasi hasil. Evaluasi proses adalah kegiatan evaluasi yang dilakukan melalui analisis hasil penilaian proses selama kegiatan pelayanan bimbingan dan konseling berlangsung. Fokus penilaian adalah keterlibatan unsur-unsur dalam pelaksanaan kegiatan bimbingan dan konseling. Dalam evaluasi ini, guru bimbingan dan konseling atau konselor juga membandingkan keberhasilan pelaksanaan program dengan standar-tandar program yang telah ditetapkan sebelumnya. Evaluasi hasil adalah kegiatan evaluasi yang dilakukan untuk memperoleh informasi tentang keefektifan layanan bimbingan dan konseling dilihat dari hasilnya. Evaluasi hal pelayanan bimbingan dan konseling ditujukan pada hasil yang dicapai olehpeserta didik yang menjalani pelayanan bimbingan dan konseling. Pencapaian ini diorientasikan pada tingkat pengentasan masalah dan perkembangan aspekaspek kepribadian peserta didik/konseli (Dokumen BK SMPN I Ibun, 2017: 22).

Prosedur evaluasi program bimbingan dan konseling dilakukan dengan langkah-langkah penyusunan rencana evaluasi, kegiatan pengumpulan data dan informasi dapat menggunakan metode-metode, seperti observasi,angket, wawancara, dan lainnya, data dan informasi yang telah diperoleh selanjutnya diolah dan duanalisis. Tahapan analisis ini sangat tergantung pada jenis dan informasi yang telah diperoleh selama proses pengumppulan data. Dalam kegiatan evaluasi program bimbingan dan konseling, guru bimbingan dan konseling atau konselor harus dapat memberikan kesimpulan akhir, apakah program maupun layanan yang dilakukan berhasil atau tidak. Upaya penentuan keberhasilan program dan kegiatan layanan bimbingan dan konseling harus dilakukan dengan cara menetapkan kriteria evaluasi yang mencakup proses maupun hasil (Wawancara dengan Guru BK, SMPN I Ibun: 10 Februari 2018).

Sarana, dalam penyediaan sarana kelengkapan bimbingan dan konseling di 
I.N. Lena

SMPN I Ibun masih perlu dilengkapi seperti buku-buku sumber yang berkaitan dengan upaya pengembangan diri siswa, alat perekam konseling dan lain-lain. Prasarana, fasilitas ruang yang terdapat dalam ruang BK adalah ruang tamu, ruang konseling individual, ruang konseling kelompok, ruang penyimpanan data dan ruang kerja staf BK (Wawancara dengan Guru BK, SMPN I Ibun: 10 Februari 2018).

Sumber anggaran biaya untuk kegiatan bimbingan konseling yang telah diprogram disesuaikan dengan kebutuhan dan sifatnya fleksibel yang berumber dari RAPBS (Dana BOS) (Dokumen BK SMPN I Ibun, 2017: 26).

Bimbingan dan konseling di SMPN I Ibun berorientasi pada pengenalan potensi, tugas perkembangan dan pencegahan masalah. Hal tersebut sejalan dengan pengertian bimbingan bimbingan yang dikemukakan oleh Abu Ahmadi (1991: 1), bahwa bimbingan merupakan bantuan yang diberikan kepada individu (peserta didik) agar dengan potensi yang dimilikinya mampu mengembangkan diri secara optimal dengan memahami dirinya, memahami lingkungan, mengatasi hambatan guna menentukan rencana masa depan yang lebih baik. Visi dan misi BK SMPN I Ibun mengarah kepada pengembangan seluruh aspek kepribadian siswa. Membantu siswa meningkatkan kualitas diri, membentuk kebiasaan yang baik pada diri siswa, membantu individu menentukan pilihan. Visi misi ini sejalan dengan prinsip bimbingan konseling dalam buku Siti Chodijah (2016: 57) yaitu bimbingan menekankan hal yang positif dan pengambilan keputusan merupakan hal yang esensial dalam bimbingan.

Jenis layanan bimbingan konseling di SMPN I Ibun sudah sesuai dengan jenis-jenis layanan bimbingan dan konseling pada umumnya yaitu meliputi bidang pribadi, bidang sosial, bidang karier, dan ditambah dengan bidang keagamaan. Seperti jenis layanan bimbingan konseling yang dikemukakan oleh Arya (2008: 15), jenis-jenis layanan bimbingan konseling meliputi bimbingan pribadi-sosial dan karir. Layanan bimbingan konseling melalui pendekatan agama di SMPN I Ibun bertujuan untuk menambah pengetahuan siswa, menanamkan nilai-nilai keagamaan, selalu berbuat baik dan mengamalkan ajaran agama. Tujuan tersebut sejalan dengan tujuan bimbingan konseling dalam buku Akhyar Saiful (2011:64), tujuan bimbingan konseling yaitu untuk pendekatan diri kepada Allah.

\section{Pelaksanaan Kegiatan Layanan Bimbingan Konseling melalui Pendekatan Agama}

Bimbingan konseling melalui pendekatan agama dilaksanakan dengan beberapa kegiatan, diantaranya membaca dan mengkaji al-Qur'an serta Asmaul Husna, 
kerohanian, sholat jum'at dan shalat dhuha berjamaah. Kegiatan membaca dan mengkaji al-Qur'an pada tanggal 02 Februari 2018 dilaksanakan oleh 103 siswa, yaitu kelas VII A, VII B, dan VII C. Sedangkan pada tanggal 03 Februari 2018 dilaksanakan oleh 95 siswa yaitu kelas VII D, VII E, dan VII F. kegiatan ini dilakukan dengan tahapan pembimbing membuka rangkaian kegiatan dengan mengucapkan salam terlebih dahulu kemudian menyapa para siswa dan menyampaikan muqodimah. Kemudian pembimbing mengarahkan siswa untuk membaca al-Qur'an. Pembimbing yang membaca al-Qur'an, kemudian siswa mengucap ulang bacaan al-Qur'an pembimbing. Siswa dibimbing untuk mempraktekkan teori ilmu tajwid dengan sebenar-benarnya. Pembimbing membacakan perkata kemudian pembimbing bertanya kepada siswa tentang tajwid yang terdapat dalam kata tersebut. Setelah itu pembimbing dan siswa mengkaji arti dari surat yang telah dibaca. Adapun surat yang dikaji pada pertemuan kali ini yaitu surat Adz-Dzariyat ayat 56 dan Al-Bayinah ayat 5. Setelah selesai mengkaji al-Qur'an beserta tajwid dan artinya, pembeimbing memberikan materi berkenaan dengan ayat tersebut. Adapun materi yang disampaikan sesuai dengan terjemah kedua ayat tersebut yaitu mengenai ibadah. Metode yang digunakan dalam kegiatan ini yaitu ceramah dan komunikasi langsung. Siswa mengikuti kegiatan ini dengan baik. hal tersebut terlihat dari respon siswa yang mengikuti pengarahan dari pembimbing dan memperhatikan pembimbing saat menyampaikan materi, juga antusias saat tanya jawab. Dari 103 siswa sekitar 40 siswa mengangkat tangannya untuk bertanya kepada pembimbing. Tetapi karena waktu yang tidak cukup, maka pembimbing hanya memberi kesempatan kepada 6 siwa untuk bertanya. Sedangkan siswa yang belum mendapat kesempatan untuk bertanya, bisa bertanya langsung kepada pembimbing di luar kegiatan tersebut. Pada tahap akhir, pembimbing melakukan tanya jawab dengan siswa mengenai materi yang telah dibahas. Setelah pembimbing menjawab pertanyaan dari siswa, pembimbing manyimpulkan materi yang telah disampaikan. Kemudian kegiatan ditutup dengan membaca do'a akhir majlis secara bersama-sama.

Dari kegiatan bimbingan membaca dan mengkaji ayat Al-Qur'an, berdasarkan wawancara yang dilakukan pada tanggal 02 Februari 2018 dengan pembimbing yaitu Ibu Marfilia Sutjiasri, S.Pd bahwa dari kegiatan membaca dan mengkaji al-Qur'an selain memperlancar bacaan al-Qur'an siswa juga dapat merubah perilaku siswa ke arah yang lebih positif, karena materi yang diberikan dalam kegiatan ini disesuaikan dengan kebutuhan siswa dan masalah yang sering terjadi di sekolah. bimbingan tersebut siswa yang membolos berkurang. Siswa yang tadinya sering berkata kasar jadi dapat diperbaiki, siswa yang suka merokok dan melanggar berbagai peraturan sekolahpun menjadi berkurang. Siswa yang tadinya tidak lancar membaca al-Qur'an menjadi lebih baik dan perilaku 
menyimpang seperti kenakalan remaja yang sering dilakukan siswa dapat ditanggulangi.

Kegiatan membaca dan mengkaji Asmaul Husna dilakukan di kelas sebelum kegiatan belajar mengajar dimulai atau di ruang BK sebelum kegiatan konseling kelompok. Kegiatan membaca dan mengkaji Asmaul Husna yang diamati dilaksanakan pada tanggal 30 Maret 2018 di ruang BK sebelum kegiatan konseling kelompok yang diikuti oleh 8 orang siswa. Sebelum melaksanakan kegiatan tersebut, guru BK atau guru mata pelajaran melakukan diskusi dengan guru agama mengenai Amaul Husna yang belum diketahui. Pembimbing dan siswa membuka buku Asmaul Husna, kemudian membaca beberapa Asmaul Husna beserta Artinya. Kemudian mengkaji artinya dengan cara mengaitkan dengan kehidupan sehari-hari. Metode yang disampaikan dalam kegiatan ini yaitu metode nasihat hikmah wal mavidzatil Hasanah yang artinya memberi pelajaran dan nasihat yang baik. Siswa mendengarkan dan menerima nasihat pembimbing dengan baik. hal tersebut terlihat dari keseriusan siswa dalam mendengarkan pembimbing dan mendengarkan pendapat temannya dengan baik saat kegiatan konseling kelompok.

Berdaarkan wawancara yang dilakukan pada tanggal 05 Februari 2018 dengan guru BK yaitu Ibu $\mathrm{Hj}$ Euis Karteja, S.Pd bahwa setelah diadakan kegiatan mengkaji Asmaul Husna sebelum kegiatan belajar mengajar, bahwa sebagian besar siswa dapat menghafal Asmaul Husna dan perilaku siswa berubah ke arah yang lebih positif. Contohnya saling mengingatkan dengan temannya, ketika mereka akan melakukan perilaku menyimpang seperti kenakalan remaja yang pernah mereka lakukan, mereka berpikir kembali karena mengetahui hal tersebut dilarang oleh agama.

Kerohanian yaitu kegiatan yang dilakukan oleh siswi setiap hari jum'at pada saat siswa melaksanakan shalat jum'at di sekolah. Kegiatan ini bertujuan untuk meningkatkan pribadi Muslimah siswi.. Kegiatan kerohanian yang diamati dilaksanakan pada tanggal 09 Februari 2018 oleh Ibu Erlin Darlina, M.M.Pd. dengan tahapan pembimbing menyampaikan muqodimah, dan dan membuka acara dengan mengucapkan basmallah. Pembimbing menyampaikan materi mengenai hubungan perilaku narsisme dengan ujub. Kemudian setelah penyampaian materi, dilakukan sesi tanya jawab atau diskusi dengan cara berkelompok dan memaparkan apa yang telah didiskusikan. Lebih dari 20 siswa mengangkat tangannya untuk bertanya, tetapi pada kesempatan kali ini hanya 10 siswa yang diberi kesempatan untuk bertanya. Sedangkan yang lainnya bisa berkonsultasi langsung dengan pembimbing atau guru BK yang lain di luar kegiatan tersebut. Kegiatan ditutup dengan menyimpulkan materi yang telah dibahas, mengucapkan hamdallah bersama-sama, kemudian mengucapkan salam.

Dari kegiatan kerohanian yang dilaksanakan oleh siswi setiap hari jum'at, berdaarkan hasil wawancara dengan pembimbing yaitu Ibu Erlin Darlina, 34

Irsyad : Jurnal Bimbingan, Penyuluhan, Konseling, dan Psikoterapi Islam 7(1) (2019) 19-40 
M.M.Pd. bahwa siswa mengalami perubahan ke arah yang lebih positif. Perubahan pertama terlihat dari cara berpakaian siswa yang tadinya sering melanggar seperti memakai rok di atas lutut, setelah mengikuti kegiatan kerohanian pakaiannya lebih sopan bahkan yang tadinya belum memakai kerudung setelah mengikuti kerohanian siswa mau untuk memakai kerudung. 50 siswa sudah tiga kali dikumpulkan oleh guru BK karena memakai rok di atas lutut. Setelah mengikuti kegiatan kerohanian, hanya 3 orang siswa yang dipanggil guru BK karena memakai rok di atas lutut.

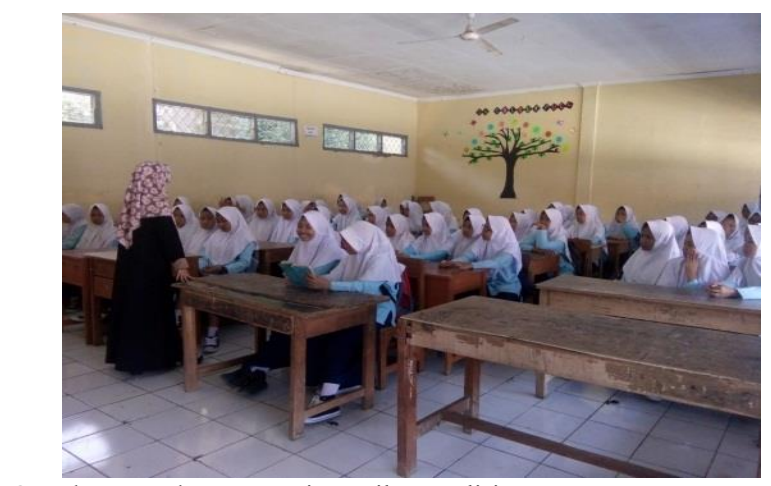

Sumber: Dokumentasi Hasil Penelitian

Gambar. 1 Kegiatan Kerohanian

Siswa wajib melakanakan shalat jum'at di sekolah dengan jadwal yang telah ditentukan. Misalnya, Minggu pertama siswa kelas VII yang melaksanakan shalat jum'at di sekolah, minggu kedua kelas VIII dan minggu ketiga kelas IX. Kegiatan shalat jum'at yang diamati dilaksanakan pada tanggal 02 Maret 2018 yang dilakanakan oleh siswa kelas VII dan dipimpin oleh Bapak Drs. Omar dengan tahapan pembimbing mengarahkan siswa untuk duduk dengan rapi sebelum melaksanakan shalat jumat. Pembimbing memberikan ceramah mengenai pentingnya menuntut ilmu. Pembimbing memebrikan materi tersebut agar siswa termotivasi untuk menuntut ilmu, memiliki semnagta belajar dan beribadah. Setelah selesai memberikan ceramah, pembimbing menunjuk salah satu siswa untuk melakukan iqamat, setelah itu pembimbing dan siswa melaksanakan shalat jumat. Setelah selesai melaksanakan shalat jumat, siswa bersalaman dengan pembimbing dan meninggalkan Mesjid dengan tertib.

Berdasarkan wawancara yang dilakukan kepada Bapak Drs. Omar, bahwa shalat jum'at yang diwajibkan di sekolah dapat menambah kedisiplinan siswa, menambah pengetahuan keagamaan dan merubah sikap siswa ke arah yang lebih positif. Siswa dapat mendengarkan ceramah dengan baik dan tertib sehingga kebiasaan tersebut dapat terbawa dalam proses belajar mengajar. Setelah mengikuti ceramah dalam shalat jumat di sekolah sudah tidak ada lagi siswa yang 
merokok. Siswa yang tadinya bolos sekolah lebih dari 5 orang sekarang berkurang menjadi 1 atau 2 orang di setiap kelas. Berdaarkan wawancara yang dilakukan pada tanggal 02 Maret 2018 kepada siswa bahwa menurut siswa kegiatan shalat jum'at dan kerohanian di sekolah dapat menambah pengetahuan keagamaan siswa karena sebelumnya mereka mengaku memiliki pengetahuan agama yang kurang karena pendidikan agama Islam di sekolah hanya diberikan 2 jam dalam satu minggu. Siswa merasa hatinya menjadi lebih tenang karena sering diingatkan untuk selalu mengingat Allah. Materi yang disampaikan dalam kegiatan tersebut menurut siswa sesuai dengan kehidupan sehari-harinya, berbeda dengan ceramah pada umumnya karena pembimbing memberi materi sesuai dengan kebutuhan siswa diusia remaja. Siswa juga terdorong untuk saling mengingatkan dengan temannya untuk tidak melanggar peraturan sekolah dan perbuatan buruk lainnya. Saat akan melakukan kenakalan remaja seperti yang pernah mereka lakukan sebelumnya, setelah mengikuti bimbingan tersebut mereka berpikir kembali untuk melakukannya karena menyadari perilaku tersebut dilarang oleh agama.

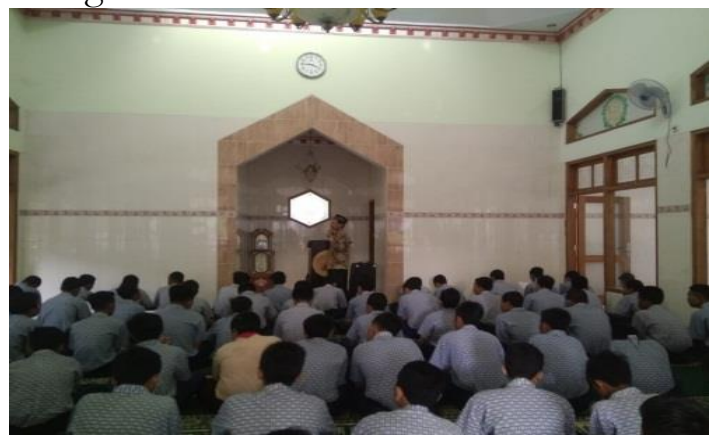

Sumber: Dokumentasi Hasil Penelitian

Gambar 2. Kegiatan Shalat Jumat di Mesjid Sekolah

Sebelum kegiatan belajar mengajar dimulai, pada hari jum'at dan sabtu dilakukan shalat dhuha terlebih dahulu. Pembimbing mengarahkan siswa untuk melaksanakan shalat dhuha. Bukan hanya siswa, tetapi pembimbing beserta guru memberikan contoh secara langsung terkait dengan pelaksaan shalat dhuha. Setelah selesai melaksanakan shalat dhuha, pembimbing mengarahkan siswa untuk masuk ke kelasnya masing-masing untuk melaksanakan kegiatan belajar mengajar. Berdasarkan observasi yang dilakukan pada tanggal 09 Maret 2018 dalam kegiatan shalat dhuha, siswa terlihat tertib dan mengikuti arahan pembimbing dengan baik. Meskipun ada sebagian kecil siswa yang masih mengobrol saat pembimbing memberikan arahan tetapi sebagian besar siswa telah mengikuti arahan pembimbing sampai selesai shalat dhuha dengan baik. Kegiatan shalat dhuha berjamaah ini dapat melatih kedisiplinan siswa, sehingga siswa terbiasa mendengarkan dan mengikuti arahan atau bimbingan dari guru dan tidak terlambat masuk sekolah, dan juga memfasilitasi siswa dalam aspek 36

Irsyad : Jurnal Bimbingan, Penyuluhan, Konseling, dan Psikoterapi Islam 7(1) (2019) 19-40 
perkembangan ketaqwaan karena siswa tetap bisa melaksanakan ibadah sunah meskipun sedang berada di sekolah. Sehingga siswa terbiasa mengisi waktu luangnya dengan hal positif.

Bimbingan dengan membaca dan mengkaji al-Qur'an juga sesuai dengan Q.S Al-Ankabut ayat 45 bahwa Allah memerintahkan untuk membaca apa yang telah diwahyukan kepadamu yaitu al-Qur'an. Setelah dilaksanakan layanan bimbingan dan konseling melalui pendekatan agama melalui kegiatan membaca dan mengkaji al-Qur'an serta Asmaul Husna, bacaan al-Qur'an siswa menjadi lebih baik, hafalannya bertambah, dan perilakunya berubah ke arah yang lebih positif. Hal ini sejalan dengan tujuan bimbingan konseling menurut Anwar Sutoyo (2013: 2016) terkait dengan aktualisasi ikhsan meliputi menjauhkan diri dari penyakit hati, menjauhkan dari perbuatan membahayakan, bersikap baik terhadap sesama muslim.

Bimbingan melalui shalat jumat, shalat dhuha dan ceramah sudah sesuai dengan jenis layanan dalam buku Dadang Ahmad Fajar (2015: 67) dan sesuai dengan Q.S Al-Ankabut ayat 45 bahwa shalat itu mencegah dari perbuatan keji dan Munkar. Layanan bimbingan konseling melalui pendekatan agama dengan shalat jum'at dan shalat dhuha dapat membuat siswa menjadi lebih disiplin dan mau mendengarkan arahan pembimbing dengan baik. sehingga siswa dapat terbiasa menjalankan ibadah sesuai dengan kemauannya sendiri. Dari perubahan tersebut terlihat bahwa tujuan bimbingan konseling dalam buku Anwar Sutoyo (2013: 216) untuk mengaktualisasikan iman dan Islam dalam kehidapat seharihari dikatakan berhasil. Tujuan tersebut meliputi beribadah dengan niat yang tulus, mendirikan shalat wajib dan shalat sunah dengan benar, mematuhi apa yang diajarkan Allah dalam al-Qur'an dan mematuhi apa yang diajarkan Rasulullah.

Metode bimbingan konseling melalui pendekan agama dilakukan melalui komunikasi langsung, ceramah, nasihat, dan diskusi. Metode yang dilakukan dalam layanan bimbingan konseling melalui pendekatan agama dilakukan untuk meyakinkan siswa pentingnya ajaran agama, mendorong untuk mengamalkan ajaran agama. Hal ini sesuai dengan tahap-tahap layanan bimbingan konseling menurut Anwar Sutoyo (2013: 214), yaitu meyakinkan individu tentang posisi manusia sebagai hamba Allah, mendorong dan membantu individu memahami dan mengamalkan ajaran agama dengan benar, mendorong dan membantu individu memahami dan mengamalkan iman, Islam, ikhsan.

Perilaku siswa berubah ke arah yang lebih positif, seperti lebih sopan dalam berpakaian, saling mengingatkan dengan sesama teman, berpikir kembali saat akan melakukan perilaku yang kurang baik, dan pengetahuan agamanya bertambah. Dari perubahan tersebut terlihat bahwa tujuan metode bimbingan konseling memalui pendekatan agama dengan nasihat dalam buku Dadang 
Ahmad Fajar (2015: 67) dikatakan berhasil. Tujuan tersebut yaitu membimbing ke arah jalan Allah, memberikan nasihat yang mengandung bimbingan bukan sekedar setumpuk penjelasan atau ceramah, memberikan nasihat sesuai dengan kebutuhan siswa.

Namun ada beberapa jenis layanan yang belum diterapkan dalam layanan bimbingan konseling melalui pendeketan agam di SMPN I Ibun yaitu melalui dzikir dan shaum. Dzikir dapat membuat hati menjadi tenang dan ketenangan hatidapat membuahkan bersihnya pikiran dan sehat jasmani. Sehingga siswa terhindar dari pikiran-pikiran untuk melakukan perilaku yang menyimpang.

Keberhasilan bimbingan konseling melalui pendekatan agama kepada siswa tergantung pada siswa itu sendiri dalam mengaktualisasikan nilai-nilai ajaran Islam. Oleh karena itu guru BK perlu meyakinkan siswa, mendorong untuk lebih memahami ajaran Islam, dan mengamalkannya dalam kehidupan sehari-hari. Hal ini sejalan dengan metode bimbingan konseling dan juga nuansa konseling dalam buku Anwar Sutoyo (2018: 217), Nuansa tersebut yaitu mengingatkan individu yang dibimbing dengan cara Allah.

\section{PENUTUP}

Berdasarkan hasil penelitian, Perolehan data, observasi dan hasil analisa datanya berkenaan dengan masalah penelitian, maka diperoleh kesimpulan program bimbingan konseling melalui pendekatan agama di SMPN I Ibun bertujuan untuk memupuk rasa keimanan siswa, menambah pengetahuan agama siswa dan mengubah perilaku siswa ke arah yang lebih positif sehingga dapat mengatasi kenakalan remaja di sekolah. Bimbingan di Sekolah berkepentingan dengan pendekatan agama. Hal ini dimaksudkan agar nilai budaya dan ilmu menyatu dengan nilai agama dengan penerapan prinsip-prinsip bimbingan konseling melalui pendekatan agama guru BK dapat menyisipkan pesan-pesan keagamaan di setiap pelaksanaan kegiatan bimbingan dan konseling. Layanan bimbingan konseling melalui pendekatan agama dilaksanakan melalui kegiatan membaca dan mengkaji al-Qur'an, membaca dan mengkaji Asmaul Husna, kerohanian, shalat dhuha dan shalat jumat. Materi yang diberikan dalam layanan bimbingan dan konseling tersebut yaitu mengenai ibadah dan keagamaan. Metode yang digunakan yaitu komunikasi langsung (konseling kelompok) dan ceramah. Media yang digunakan yaitu mimbar, alat tulis, al-Qur'an dan alat-alat lainnya. Keadaan pemahaman keislaman siswa setelah mengikuti layanan bimbingan konseling melalui pendekatan agama dinyatakan baik terutama keadaan rohani siswa. Layanan bimbingan konseling melalui pendekatan agama dapat merubah siswa ke arah yang lebih positif dan dinyatakan berhasil dalam segi perubahan pemahaman siswa tetapi belum optimal dalam perubahan sikap siswa. Walaupun demikian, layanan bimbingan konseling melalui pendekatan agama dapat 
membuat siswa menyadari kenakalan remaja dilarang oleh agama bukan hanya oleh peraturan sekolah, sehingga dapat mengurangi kenakalan remaja di SMPN I Ibun.

Sehubungan dengan apa yang peneliti temukan dalam penelitian ini ada beberapa saran yang dikemukakan pada akhir bab ini, dengan harapan dapat menjadi sumbangan positif dalam pelaksanaan layanan bimbingan konseling di SMPN I Ibun. Berdasarkan penelitian yang telah dilakukan, bahwa guru BK yang berjumlah 7 orang tidak sesuai dengan jumlah siswa sebanyak 1.327 orang. Oleh karena itu, bagi pihak sekolah atau kepala sekolah yang berwenang agar menambah lagi guru BK, karena dengan hanya tujuh guru BK dengan jumlah siswa sebanyak 1.327 dirasakan kurang efektif dalam melaksanakan layanan bimbingan dan konseling. Berdasarkan penelitian yang telah dilakukan diperoleh hasil bahwa siswa berubah ke arah yang lebih positif dari segi pemahaman, tetapi belum optimal dari segi sikap. Oleh karena itu bagi guru BK, agar meningkatkan program dan layanan bimbingan konseling melalui pendekatan agama sehingga perilaku siswa semakin berubah ke arah yang lebih positif.

Dari hasil wawancara dengan siswa, banyak siswa yang merasa malu untuk berkonsultasi dengan guru BK dan takut datang ke ruang BK karena siswa yang dipanggil ke ruang BK kebanyakan adalah siswa yang bermasalah. Oleh karena itu bagi siswa diharapkan bisa memanfaatkan layanan bimbingan dan konseling semaksimal mungkin. Tidak perlu merasa malu dan takut untuk datang ke ruang BK dan berkonsultasi dengan guru BK.

\section{DAFTAR PUSTAKA}

Ahmad, A. (2005). Psikologi Perkembangan. Jakarta: PT Rineka Cipta.

Ali, M. (2008). Psikologi Remaja. Jakarta: PT Bumi Aksara.

Aminarti, Y. (2013). Studi Kepustakaan Mengenai Landasan Teori dan Praktik

Konseling Resolusi Konflik Interperonal dalam Jurnal Mahasiswa Bimbingan Konseling, 1(3).

Arifin, M. (2003). Ilmu Pendidikan Islam. Jakarta: Bumi Akara.

Chodijah, S. (2016). Pengantar Bimbingan dan Konseling Pendidikan. Bandung: CV Mimbar Pustaka.

Daradjat, Z. (2003). Ilmu Jiwa Agama. Jakarta: Bulan Bintang.

Dewi, Y., (2017). Faktor Penyebab Tergabungnya Remaja Kota Bandung Dalam

Komunitas Kenakalan Remeja. Share Social Work Journal 7 (1)

Dwinita, D., (2012). Pelaksanaan Bimbingan Konseling Anak Berkebutuhan Khusus Di Smk N 4 Padang E- 1 (3) Jupekbu

Fajar, D. A. (2015). Psikoterapi Religius. Cianjur: Darr Dzikir Press.

Kahmad, D. (2006). Sosiologi Agama. Bandung: PT Remaja Rosdakarya. 
I.N. Lena

Khermarinah, K. (2017) Problematika Kenakalan Pada Kalangan Remaja. AtTa'lim : Media Informasi Pendidikan Islam 16, (2)

Marlina, E. (2012). Motivasi Berpuasa Ramadhan dan Moralitas Remaja dalam Ilmu Dakwah: Academic Journal for Homiletic Studies, 2(6), 250.

Merryana, (2013). Peran Bimbingan Konseling (Bk) Dalam Mengatasi Kenakalan

Remaja Di Sekolah Menengah Pertama Negeri Nomor 17 Pontianak, Sociodev, 2 (1)

Musbikin, I. (2008). Melogikakan Rukun Islam (Bagi Kebutuban Fisik dan Pisikologi Manusia. Yogyakarta: Diva Press.

Nawawi, H. H. (2003). Pendidikan Dalam Islam. Surabaya: Al-Ikhlas.

Nurfadlilah, H. (2016). Bimbingan Keagamaan Melalui PAP (Persiapan Apel Pagi)

Untuk Meningkatkan Kesadaran Beragama Pada Remaja. Skripsi, Jurusan Bimbingan dan Konseling Islam, UIN Sunan Gunung Djati, Bandung.

Nurhasanah, L. (2017). Kenakalan Remaja dalam Perspektif Antropologi dalam Konseli: Jurnal Bimbingan dan Konseling, 1(4).

Saepulrohim, A. (2016). Manajemen Bimbingan dan Konseling Islam. Bandung: CV. Mimbar Pustaka.

Sahaburohman, R. D. (2016). Bimbingan Agama untuk Membangun Akblakul Karimah Remaja di Pondok Pesantren Al-Baroroh (Studi Dekriptif di Pondok Peantren Al-Baroroh Limbangan-Garut). Skripsi, Jurusan Bimbingan dan Konseling Islam, UIN Sunan Gunung Djati, Bandung.

Saiful, A. (2011). Konseling Islami dan Kesehatan Mental. Yogyakarta: Cita Pustaka.

Salahudin, A. (2010). Bimbingan \& Konseling. Bandung: CV Pustaka Setia.

Satriah, L. (2015). Bimbingan dan Konseling Kelompok. Bandung: CV Mimbar Pustaka.

Sukardi, D. K. (2008). Pengantar Pelaksanaan Program Bimbingan dan Konseling di Sekolah. Jakarta: Rineka Cipta.

Sukayat, T. (2012). Revitalisasi Ilmu Dakwah: Kajian Mabadi 'Asrah Ilmu Dakwah dalam Ilmu Dakwah: Academic Journal for Homiletic Studies, 2(6), 201 203.

Sutoyo, Anwar. 2013. Bimbingan dan Konseling Islami. Yogyakarta: Penerbit Pustaka Pelajar.

Tamayao I.,(2017). Efektifitas Metode Pendekatan Sosiologi Personal Dalam Meminimalisasi Terhadap Kenakalan Remaja (Studi Di Smp Negeri 1 Boyolangu) Jurnal Rontal Keilmuan Pancasila dan Kewarganegaraan 3,(2)

Walgito, B. (2010). Bimbingan dan Konseling. Yogyakarta: Penerbit Andi.

Willis, S Sofyan. 2014. Konseling Individu. Bandung: Alfabeta.

Yandri, dkk. (2013)Pengembangan Modul Bimbingan Dan Konseling Untuk Pencegahan Bullying Di Sekolah 2,(1) Konselor. 